\title{
Biodiversity of the Upper Slope Demersal Community in the Eastern Mediterranean: Preliminary Comparison BetweenTwo Areas With and Without Trawl Fishing
}

\author{
G. D'Onghia, F. Mastrototaro and A. Matarrese \\ Department of Zoology, University of Bari, Via Orabona, 4 - 70125 Bari, Italy \\ C.-Y. Politou and Ch. Mytilineou \\ National Centre for Marine Research, Aghios Kosmas, Hellinikon, 16604, Greece
}

\begin{abstract}
Univariate diversity indices and multivariate analyses (cluster and multidimensional scaling (MDS) were performed in order to evaluate biodiversity in two neighbouring areas of the Eastern Mediterranean with different fishing intensity. Data were collected from two trawl surveys (July and August 2000) in two areas of the Ionian Sea. In the area off the South-eastern Italian coast, there is a trawl fishery at depths between 300 and $700 \mathrm{~m}$ that targets the deep-sea shrimps Aristeus antennatus and Aristaeomorpha foliacea. In the other area off Northern Greece, fishing is only carried out down to $400 \mathrm{~m}$ depth.

While diversity indices did not show convincing differences in the community structure between the two study areas considered as a whole, the multivariate analysis showed a clear pattern linked to depths and areas highlighting the distribution of abundance of the various species. Depth played the main role in the group differentiation, indicating the existence of two quite distinct bathyal faunal assemblages: one on the upper slope, the other on the middle slope. The results of the geographic characterization of the diversity and of the assemblage composition are discussed considering the different fishing intensity as well as the environmental conditions in the two areas of the same basin.
\end{abstract}

Key words: abundance, biodiversity, demersal community, environment, Mediterranean Sea

\section{Introduction}

The Ionian Sea is a basin of the Eastern Mediterranean, delimited westwards and eastwards by the Italian and Greek coasts, respectively. It communicates with the western Mediterranean through the Sicilian Channel, with the Adriatic through the Otranto Channel, and with the Aegean Sea through the three straits of the Western Cretan Arc. Such a position results in a complex hydrography owing to the occurrence of three main water masses, namely the Modified North Atlantic Water, the Levantine Intermediate Water, and the Eastern Mediterranean Deep Water (Theocharis et al., 1993; Rabitti et al., 1994). Knowledge on the distribution and abundance of the demersal fauna in the Ionian basin comes mostly from the Italian side, where systematic surveys of the demersal resources have been carried out since 1985 (e.g. Tursi and D'Onghia, 1992; Matarrese et al., 1996; D'Onghia et al., 1998). The demersal fish fauna of the Greek Ionian Sea, as well as the fauna of crustacean decapods and cephalopods, has only recently been studied (Anon., 1999; Anon., 2000; Politou et al., 2000). While along the Italian coasts the demersal resources have long been intensively exploited as deep as $800 \mathrm{~m}$ (Tursi et al., 1998), off Greece the commercial fishery is only carried out down to $400 \mathrm{~m}$.

Although both the hydrographic features and the fishing intensity could affect the distribution and abundance of many species, thereby influencing the diversity in marine ecosystems, the faunistic assemblages on the two sides of the Ionian Sea (Italian and Greek) have never been compared. Furthermore, although in the last decade many studies on the effects of fishing on ecosystem structure and processes have been carried out (e.g. Jennings and Kaiser, 1998, and references therein; Hall, 1999, and references therein), knowledge of the effects of trawl fishing on the fish communities in the Mediterranean is still rather scanty (e.g. Stergoiu et al., 1997; Ungaro et al., 1998; Moranta et al., 2000; Pranovi et al., 2000). 
The "INTERREG" project, funded jointly by the European Commission and the Italian and Greek governments, provided the opportunity to investigate two areas of the North Ionian Sea, which are subjected to different levels of fishing intensity. One is off the South-eastern Italian coast, where deep-water fishing occurs, and the other is off Northern Greece, where there is no deep trawl fishing. In this paper, observations concerning the faunal assemblages and the relative biodiversity are presented.

\section{Materials and Methods}

Data were collected during two trawl surveys (July and August 2000) carried out in two areas of the Ionian Sea (Eastern Mediterranean): one off the Southeastern Italian coast, the other off the Northern Greece (Fig.1). In the former trawl fishing occurs between 300 and $700 \mathrm{~m}$ targetting the deep-sea shrimps Aristeus antennatus and Aristaeomorpha foliacea (Tursi et al., 1998), in the latter fishing is carried out down to $400 \mathrm{~m}$ in depth.

A total of 14 hauls, each lasting 1 hour, were randomly taken in each area between 300 and $750 \mathrm{~m}$. The same commercial fishing vessel equipped with a bottom trawl (Italian type, with $20 \mathrm{~mm}$ stretched mesh size in the cod-end) was used. Fishes, crustaceans, cephalopods and benthic species captured in each haul were sorted into species, counted and weighed. The data for each species were expressed as number and weight of individuals per hour of trawling. Each species was coded with a number. Hauls were coded by geographical area $(I=$ Italy; $G=$ Greece). Species recorded in a single or very few hauls and represented by few specimens (such as the strictly benthic invertebrates) were excluded from the computations. Species known to be typically pelagic were omitted, unless a frequent and abundant finding was observed with the gear used. Species diversity was computed using the following univariate ecological indexes: Shannon-Wiener diversity index $\mathrm{H}^{\prime}$ (using $\log _{\mathrm{e}}$ ); Margalef species richness D (using $\log _{\mathrm{e}}$ transformation), and Pielou's evenness J (Magurran, 1991). Both abundance $(\mathrm{N} / \mathrm{h})$ and biomass $(\mathrm{kg} / \mathrm{h})$ data were used in index computation. The t-test was applied in order to detect significant differences between the two areas.

Matrices of the numbers- and weights-per-hour of each species from each station were compiled. Basic data were log-transformed to reduce the influence of the most abundant species. Classification and ordination were performed in order to identify demersal faunal assemblages in the two geographic study areas. The former was made by means of cluster analysis using the Euclidean distance coefficient and the complete linkage method (Ludwig and Reynolds, 1988), the latter through non-parametric multidimensional scaling analysis (Kruskal, 1964). All

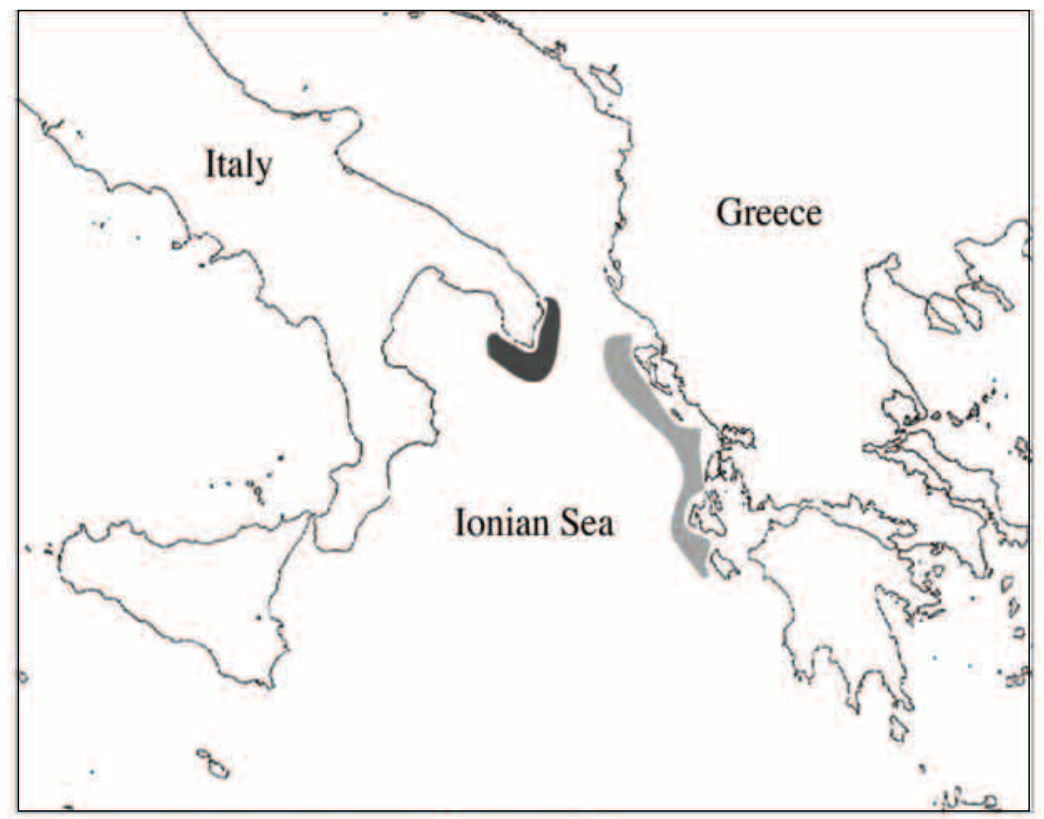

Fig. 1. Investigated areas along Italian and Greek coast. 
these analyses were carried out using Statistica software (StatSoft, 1995).

\section{Results}

According to the selection criteria, 101 species were collected in Italian waters and 112 in the Greek area. The average hourly abundance $(\mathrm{N} / \mathrm{h})$ and biomass $(\mathrm{kg} / \mathrm{h})$ for each of them are shown in Table 1 .

Teleost fishes were the dominant species in both areas (38 off Italy and 45 off Greece), followed by crustaceans (31 and 26 off Italy and Greece, respectively), cephalopods (11 along the Italian coasts and 14 along Greek ones), selachians (6 and 9 off Italy and off Greece, respectively) and other minor taxa.

Diversity indices for each station are reported in Table 2. H' ranged from 0.87 to 2.43 in Italian waters and from 1.2 to 2.67 in Greek area. Margalef species richness indexes D were between 2.88 and 3.76 in the Italian stations and 3.04 and 3.74 in Greek ones. Evenness values were between 0.25 and 0.74 off Italy and 0.33 and 0.79 off Greece. Although each index showed higher values for Greece than for Italy, the differences were not statistically significant $(p>0.05)$.

The cluster analysis showed that the abundance value $(\mathrm{N} / \mathrm{h})$ produced a better group separation than biomass $(\mathrm{Kg} / \mathrm{h})$, even though the results obtained were consistent. Concerning abundance, the resulting dendrogram between hauls indicated the presence of two main clusters related to depth (Fig. 2). One group is the uppermost stations (A), covering a depth range of 327-478 m, with a mean depth of $370 \mathrm{~m}$. The other is related to deeper hauls (B), including the intermediate stations with depths between 513 and $683 \mathrm{~m}$, and a mean of $572 \mathrm{~m}$ (B1), and the deepest stations, between 592 and $757 \mathrm{~m}$, with a mean of 669 $\mathrm{m}$ (B2). For each of these clusters a lower distance (higher similarity) was shown within each geographic area. In fact, Italian and Greek hauls were well separated in each of them. However, in cluster B2 the deepest hauls of Italian and Greek waters showed a higher similarity than the shallowest in Italian waters (between 592-629 m).

The results of multidimensional scaling (MDS) (stress level $=0.05$ ) are shown as a three dimensional representation in Fig. 3. The ordination of the 28 hauls was in agreement with clustering, confirming that the different stations fall into distinct groupings. In particular, MDS analysis highlights: a) a marked separation between the uppermost and middle slope stations; b) a marked geographic separation of the hauls in the uppermost slope; c) to a lesser extent, a geographic characterization of the stations in the middle slope.

On the basis of both clustering and MDS analysis, the uppermost assemblage in the Greek area was characterized by a great abundance of Chlorophthalmus agassizii and to a lesser extent by Hymenocephalus italicus, Plesionika heterocarpus, Parapenaeus longirostris, Gadiculus argenteus, Argentina sphyraena, Capros aper, Caelorhynchus caelorhynchus, Peristedion cataphractum, Galeus melastomus, Merluccius merluccius, Pagellus bogaraveo, Micromesistius poutassou, Scyliorhinus canicula, Raya oxyrinchus and Squalus blainvillei. A total of 67 species in this assemblage gave a diversity index $\left(\mathrm{H}^{\prime}\right)$ of 1.5. The dominant species in the uppermost assemblage of the Italian area were much less abundant than in Greece. They were: Plesionika heterocarpus, Gadiculus argenteus, Hymenocephalus italicus, Nephrops norvegicus, Chlorophthalmus agassizii, Phycis blennoides, Helicolenus dactylopterus, Parapenaeus longirostris, Galeus melastomus and Micromesistius poutassou. Apart from G. melastomus no elasmobranch species were found in this assemblage, which consisted of 51 species. Its computed diversity index $\left(\mathrm{H}^{\prime}\right)$ was 2.5 .

The assemblages in the middle slope showed a greater similarity between the two areas. The diversity index computed for the deepest group of stations (B2) was 2.48 in both areas. However, in addition to the different distribution of the species abundance, Aristaeomorpha foliacea and Helicolenus dactylopterus dominated in Greek waters while Plesionika martia and Aristeus antennatus did so in Italian ones.

\section{Discussion}

The results of this study indicate that depth and geographical area are the main factors influencing the faunal assemblages in the North-eastern Ionian Sea.

Univariate diversity indices do not show significant differences between the community structure of the two study areas considered as a whole. Moreover, the diversity index $\mathrm{H}^{\prime}$ was found to be higher in the uppermost assemblage from the Italian area where there is a trawl fishery. The smaller value 
TABLE 1. List of the species collected in Italian and Greek areas with indications of average density $(\mathrm{N} / \mathrm{h})$ and biomass indices $(\mathrm{Kg} / \mathrm{h})$. For the colonial species Isidella elongata only the biomass index is reported.

\begin{tabular}{|c|c|c|c|c|}
\hline \multicolumn{2}{|c|}{ Italy } & \multirow[b]{2}{*}{ SPONGES } & \multicolumn{2}{|c|}{ Greece } \\
\hline & & & & \\
\hline $\mathrm{Kg} / \mathbf{h}$ & $\mathbf{N} / \mathbf{h}$ & & $\mathbf{N} / \mathbf{h}$ & $\mathrm{Kg} / \mathrm{h}$ \\
\hline \multirow[t]{2}{*}{0.000} & 0.095 & Calthropella pathologica & 0.000 & 0.000 \\
\hline & & CNIDARIANS & & \\
\hline 0.042 & 2.747 & Actinauge richardi & 0.000 & 0.000 \\
\hline 0.001 & 1.240 & Adamsia palliata & 0.286 & 0.000 \\
\hline 0.000 & 0.000 & Calliactis parasitica & 0.500 & 0.000 \\
\hline 0.000 & 0.000 & Caryophyllia smithi & 0.500 & 0.000 \\
\hline 0.000 & 0.000 & Desmophyllum cristagalli & 0.357 & 0.000 \\
\hline 0.000 & 0.000 & Funiculina quadrangularis & 0.143 & 0.000 \\
\hline 0.000 & 0.000 & Isidella elongata & - & 0.092 \\
\hline 0.003 & 2.000 & Kophobelemnon leukarti & 0.000 & 0.000 \\
\hline \multirow[t]{2}{*}{0.003} & 1.786 & Pennatula rubra & 0.000 & 0.000 \\
\hline & & BRACHIOPODS & & \\
\hline \multirow[t]{2}{*}{0.000} & 0.262 & Gryphus vitreus & 2.643 & 0.016 \\
\hline & & SCAPHOPODS & & \\
\hline \multirow[t]{2}{*}{0.001} & 0.571 & Dentalium $s p$. & 0.000 & 0.000 \\
\hline & & GASTROPODS & & \\
\hline 0.000 & 0.000 & Aporrhais pespelecani & 0.286 & 0.000 \\
\hline 0.000 & 0.000 & Argobuccinum olearium & 0.071 & 0.000 \\
\hline 0.003 & 0.143 & Cassidaria echinophora & 0.000 & 0.000 \\
\hline \multirow[t]{2}{*}{0.014} & 0.143 & Tethys fimbria & 0.000 & 0.000 \\
\hline & & BIVALVES & & \\
\hline \multirow[t]{2}{*}{0.000} & 0.190 & Delectopecten vitreus & 0.000 & 0.000 \\
\hline & & CEPHALOPODS & & \\
\hline 0.000 & 0.071 & Abralia verany & 0.321 & 0.002 \\
\hline 0.001 & 0.071 & Ancistroteuthis lichtensteinii & 0.000 & 0.000 \\
\hline 0.001 & 0.071 & Brachioteuthis riise $i$ & 0.000 & 0.000 \\
\hline 0.013 & 0.143 & Histioteuthis reversa & 0.071 & 0.004 \\
\hline 0.000 & 0.000 & Illex coindetii & 0.190 & 0.001 \\
\hline 0.000 & 0.000 & Loligo forbesii & 1.524 & 0.364 \\
\hline 0.001 & 0.071 & Neorossia caroli & 0.657 & 0.008 \\
\hline 0.081 & 1.286 & Octopus salutii & 0.000 & 0.000 \\
\hline 0.000 & 0.000 & Onychoteuthis banksii & 0.071 & 0.001 \\
\hline 0.178 & 0.864 & Pteroctopus tetracirrhus & 0.679 & 0.293 \\
\hline 0.000 & 0.000 & Rondeletiola minor & 0.286 & 0.000 \\
\hline 0.020 & 0.286 & Rossia macrosoma & 0.714 & 0.021 \\
\hline 0.003 & 0.214 & Scaeurgus unicirrhus & 0.190 & 0.003 \\
\hline 0.000 & 0.000 & Sepia elegans & 1.714 & 0.016 \\
\hline 0.000 & 0.000 & Sepia orbignyana & 0.190 & 0.003 \\
\hline 0.034 & 7.286 & Sepietta oweniana & 9.429 & 0.032 \\
\hline 1.074 & 3.238 & Todarodes sagittatus & 0.393 & 0.189 \\
\hline
\end{tabular}


TABLE 1. (Continued). List of the species collected in Italian and Greek areas with indications of average density $(\mathrm{N} / \mathrm{h})$ and biomass indices $(\mathrm{Kg} / \mathrm{h})$. For the colonial species Isidella elongata only the biomass index is reported.

\begin{tabular}{|c|c|c|c|c|}
\hline & & SIPUNCULANS & & \\
\hline \multirow[t]{2}{*}{0.000} & 0.000 & Sipunculus nudus & 0.143 & 0.001 \\
\hline & & CRUSTACEANS & & \\
\hline 0.003 & 1.786 & Aegeon lacazei & 0.286 & 0.000 \\
\hline 0.435 & 47.976 & Aristaeomorpha foliacea & 248.457 & 4.401 \\
\hline 1.808 & 81.429 & Aristeus antennatus & 27.300 & 0.869 \\
\hline 0.001 & 0.214 & Bathynectes maravigna & 0.964 & 0.009 \\
\hline 0.016 & 11.929 & Chlorotocus crassicornis & 1.810 & 0.003 \\
\hline 0.000 & 0.000 & Dardanus arrosor & 0.143 & 0.004 \\
\hline 0.015 & 0.221 & Geryon longipes & 0.000 & 0.000 \\
\hline 0.017 & 7.357 & Macropipus tuberculatus & 0.286 & 0.001 \\
\hline 0.003 & 0.929 & Monodaeus couchii & 0.000 & 0.000 \\
\hline 0.002 & 0.786 & Munida intermedia & 0.071 & 0.000 \\
\hline 0.000 & 0.000 & Munida iris & 4.857 & 0.004 \\
\hline 0.001 & 0.649 & Munida perarmata & 0.071 & 0.000 \\
\hline 0.960 & 83.641 & Nephrops norvegicus & 4.395 & 0.290 \\
\hline 0.005 & 0.786 & Pagurus alatus & 0.143 & 0.000 \\
\hline 0.002 & 0.578 & Pagurus prideaux & 0.143 & 0.000 \\
\hline 0.186 & 15.214 & Parapenaeus longirostris & 110.386 & 0.520 \\
\hline 0.042 & 0.149 & Paromola cuvieri & 0.143 & 0.066 \\
\hline 0.012 & 2.214 & Pasiphaea multidentata & 0.314 & 0.002 \\
\hline 0.001 & 0.435 & Pasiphaea sivado & 0.086 & 0.250 \\
\hline 0.002 & 1.381 & Plesionika acanthonotus & 6.393 & 0.007 \\
\hline 0.000 & 0.143 & Plesionika antigai & 43.024 & 0.037 \\
\hline 0.000 & 0.000 & Plesionika edwardsii & 10.750 & 0.100 \\
\hline 0.016 & 10.714 & Plesionika gigliolii & 19.226 & 0.023 \\
\hline 0.346 & 148.143 & Plesionika heterocarpus & 178.000 & 0.294 \\
\hline 3.565 & 805.913 & Plesionika martia & 281.686 & 1.243 \\
\hline 0.001 & 0.143 & Plesionika narval & 0.000 & 0.000 \\
\hline 0.109 & 52.333 & Polycheles typhlops & 8.536 & 0.040 \\
\hline 0.002 & 0.929 & Pontophilus spinosus & 0.000 & 0.000 \\
\hline 0.000 & 0.214 & Pontophyllus norvegicus & 0.000 & 0.000 \\
\hline 0.014 & 13.143 & Processa canaliculata & 0.000 & 0.000 \\
\hline 0.002 & 0.429 & Rissoides pallidus & 0.000 & 0.000 \\
\hline 0.000 & 0.299 & Sergestes arcticus & 0.171 & 0.000 \\
\hline 0.000 & 0.214 & Sergestes corniculum & 0.338 & 0.000 \\
\hline \multirow[t]{2}{*}{0.044} & 22.877 & Solenocera membranacea & 0.000 & 0.000 \\
\hline & & ECHINODERMS & & \\
\hline 0.000 & 0.000 & Astropecten aranciacus & 0.071 & 0.014 \\
\hline 0.000 & 0.000 & Astropecten irregularis pentacanthus & 0.071 & 0.000 \\
\hline 0.016 & 1.500 & Brisingella coronata & 0.143 & 0.000 \\
\hline 0.065 & 2.143 & Cidaris cidaris & 2.214 & 0.028 \\
\hline 0.019 & 2.500 & Echinus acutus & 0.071 & 0.000 \\
\hline 0.000 & 0.000 & Marginaster capreensis & 0.071 & 0.000 \\
\hline 0.009 & 0.357 & Mesothuria intestinalis & 0.071 & 0.000 \\
\hline 0.000 & 0.000 & Sclerasterias neglecta & 0.214 & 0.000 \\
\hline 0.023 & 0.143 & Stichopus regalis & 0.000 & 0.000 \\
\hline
\end{tabular}


TABLE 1. (Continued). List of the species collected in Italian and Greek areas with indications of average density (N/h) and biomass indices $(\mathrm{Kg} / \mathrm{h})$. For the colonial species Isidella elongata only the biomass index is reported.

\begin{tabular}{|c|c|c|c|c|}
\hline & & SELACHIANS & & \\
\hline 0.149 & 0.775 & Chimaera monstrosa & 0.000 & 0.000 \\
\hline 0.015 & 0.071 & Dalatias licha & 0.000 & 0.000 \\
\hline 0.848 & 25.045 & Etmopterus spinax & 2.086 & 0.140 \\
\hline 7.966 & 52.407 & Galeus melastomus & 57.564 & 6.150 \\
\hline 0.000 & 0.000 & Heptranchias perlo & 0.286 & 0.229 \\
\hline 0.000 & 0.000 & Mustelus mustelus & 0.214 & 1.200 \\
\hline 0.035 & 0.214 & Raja circularis & 0.000 & 0.000 \\
\hline 0.000 & 0.000 & Raja clavata & 0.238 & 0.152 \\
\hline 0.016 & 0.078 & Raja oxyrinchus & 1.238 & 0.748 \\
\hline 0.000 & 0.000 & Raja spp. (juvenile forms) & 0.286 & 0.188 \\
\hline 0.000 & 0.000 & Scyliorhinus canicula & 1.333 & 0.204 \\
\hline \multirow[t]{2}{*}{0.000} & 0.000 & Squalus blainvillei & 1.000 & 0.850 \\
\hline & & FISH & & \\
\hline 0.004 & 0.864 & Antonogadus megalokynodon & 0.143 & 0.001 \\
\hline 0.007 & 0.286 & Argentina sphyraena & 51.000 & 0.707 \\
\hline 0.000 & 0.227 & Argyropelecus hemigymnus & 0.479 & 0.002 \\
\hline 0.000 & 0.000 & Arnoglossus rueppelli & 2.571 & 0.012 \\
\hline 0.002 & 0.095 & Benthocometes robustus & 0.000 & 0.000 \\
\hline 0.000 & 0.000 & Benthosema glaciale & 0.929 & 0.001 \\
\hline 0.143 & 12.381 & Caelorhynchus caelorhynchus & 44.857 & 0.503 \\
\hline 0.000 & 0.000 & Capros aper & 40.857 & 1.186 \\
\hline 0.000 & 0.000 & Centrolophus niger & 0.214 & 0.611 \\
\hline 0.000 & 0.071 & Ceratoscopelus maderensis & 0.143 & 0.000 \\
\hline 0.001 & 0.143 & Chauliodus sloani & 2.307 & 0.027 \\
\hline 0.348 & 69.084 & Chlorophthalmus agassizii & 2031.690 & 17.114 \\
\hline 0.694 & 1.000 & Conger conger & 2.000 & 0.043 \\
\hline 0.000 & 0.000 & Diaphus holti & 0.086 & 0.000 \\
\hline 0.000 & 0.000 & Diaphus metopoclampus & 0.071 & 0.001 \\
\hline 0.000 & 0.071 & Diaphus rafinesquei & 0.000 & 0.000 \\
\hline 0.000 & 0.000 & Epigonus constanciae & 0.714 & 0.014 \\
\hline 0.005 & 0.214 & Epigonus telescopus & 0.000 & 0.000 \\
\hline 0.344 & 117.000 & Gadiculus argenteus & 70.952 & 0.285 \\
\hline 0.980 & 30.472 & Helicolenus dactylopterus & 40.788 & 6.249 \\
\hline 1.936 & 34.323 & Hoplostethus mediterraneus & 45.021 & 2.950 \\
\hline 0.626 & 193.017 & Hymenocephalus italicus & 281.343 & 1.039 \\
\hline 0.047 & 4.551 & Lampanyctus crocodilus & 23.774 & 0.273 \\
\hline 0.221 & 0.143 & Lepidopus caudatus & 0.000 & 0.000 \\
\hline 0.076 & 2.500 & Lepidorhombus bosci & 9.500 & 0.877 \\
\hline 0.000 & 0.000 & Lepidorhombus whiffiagonis & 1.202 & 0.315 \\
\hline 0.000 & 0.000 & Lepidotrigla dieuzeidei & 7.024 & 0.230 \\
\hline 0.180 & 0.857 & Lophius budegassa & 0.514 & 0.689 \\
\hline 2.339 & 0.286 & Lophius piscatorius & 0.264 & 3.546 \\
\hline
\end{tabular}


TABLE 1. (Continued). List of the species collected in Italian and Greek areas with indications of average density $(\mathrm{N} / \mathrm{h})$ and biomass indices $(\mathrm{Kg} / \mathrm{h})$. For the colonial species Isidella elongata only the biomass index is reported.

\begin{tabular}{|c|c|c|c|c|}
\hline 0.010 & 24.286 & Maurolicus muelleri & 10.667 & 0.010 \\
\hline 1.090 & 2.292 & Merluccius merluccius & 24.717 & 2.626 \\
\hline 0.000 & 0.000 & Microichthys coccoi & 0.071 & 0.000 \\
\hline 0.714 & 5.571 & Micromesistius poutassou & 6.071 & 0.721 \\
\hline 0.088 & 2.143 & Molva dipterygia & 0.857 & 0.200 \\
\hline 0.412 & 20.019 & Mora moro & 5.400 & 0.337 \\
\hline 0.000 & 0.071 & Myctophum punctatum & 0.571 & 0.000 \\
\hline 0.001 & 0.071 & Nemichthys scolopaceus & 0.000 & 0.000 \\
\hline 0.058 & 1.071 & Nettastoma melanurum & 4.586 & 0.242 \\
\hline 1.363 & 114.561 & Nezumia sclerorhynchus & 42.543 & 0.468 \\
\hline 0.033 & 2.221 & Notacanthus bonapartei & 0.000 & 0.000 \\
\hline 0.001 & 0.095 & Oligopus ater & 0.000 & 0.000 \\
\hline 0.000 & 0.143 & Ophidion barbatum & 0.000 & 0.000 \\
\hline 0.000 & 0.000 & Pagellus acarne & 0.095 & 0.014 \\
\hline 0.000 & 0.000 & Pagellus bogaraveo & 7.893 & 0.924 \\
\hline 0.000 & 0.000 & Peristedion cataphractum & 37.190 & 0.859 \\
\hline 2.726 & 42.630 & Phycis blennoides & 26.317 & 1.543 \\
\hline 0.000 & 0.000 & Polyprion americanum & 0.071 & 0.279 \\
\hline 0.001 & 0.071 & Stomias boa & 3.443 & 0.046 \\
\hline 0.002 & 0.214 & Symbolophorus veranyi & 0.000 & 0.000 \\
\hline 0.000 & 0.000 & Symphurus ligulatus & 0.214 & 0.001 \\
\hline 0.001 & 0.143 & Symphurus nigrescens & 0.000 & 0.000 \\
\hline 0.000 & 0.000 & Synchiropus phaeton & 4.357 & 0.016 \\
\hline 0.000 & 0.000 & Trachurus trachurus & 0.095 & 0.052 \\
\hline 1.269 & 5.143 & Trachyrhynchus trachyrhynchus & 0.000 & 0.000 \\
\hline 0.000 & 0.000 & Trigla lucerna & 0.286 & 0.062 \\
\hline 0.002 & 0.429 & Trigla lyra & 0.357 & 0.041 \\
\hline
\end{tabular}

of $\mathrm{H}^{\prime}$ shown in the Greek assemblage, made up of a higher number of species, is most probably due to the high dominance of one (C. agassizii) or few species. According to Murawski (2000), the greater H' value shown in Italian waters might be caused by exploitation giving rise to an increase in evenness and thus of diversity. At the deepest stations the computed diversity index indicates a similar structure of the assemblages in Italian and Greek waters, however it does not take into account the role of the different species in the two geographical areas.

On the contrary, multivariate analysis shows a clear pattern linked to depths and areas highlighting the distribution of abundance of the various species. In particular, depth plays the main role in the group differentiation, indicating the existence of two quite distinct bathyal faunal assemblages, which are separated by the 400-500 m bathymetric zone. These results are in agreement with previous observations made in the western Ionian Sea (D'Onghia et al., 1998) and in other Mediterranean areas (e.g. Abellò et al., 1988; Biagi et al., 1989; Cartes et al., 1994; Abella and Serena, 1995; Stefanescu et al., 1994; Ungaro et al., 1995). They confirm that the transition between an upper slope fauna and a strictly bathyal fauna is located at about 400-500 m (Pérès and Picard, 1964; Abellò et al., 1988; Mura and Cau, 1994).

Concerning the geographic characterization of the stations shown in this study, the question is whether such a characterization, as shown in several case 
TABLE 2. Ecological index of Diversity ( $\left.\mathrm{H}^{\prime}\right)$, Richness (D) and Evenness (J) calculated for each haul in the Italian and Greek areas.

\begin{tabular}{cccccccccc}
\hline \hline & \multicolumn{3}{c}{ Italy } & \multicolumn{7}{c}{ Greece } \\
Haul & $\begin{array}{c}\text { Depth } \\
(\mathrm{m})\end{array}$ & \multicolumn{1}{c}{$\mathrm{H}^{\prime}$} & $\mathrm{D}$ & $\mathrm{J}$ & $\mathrm{Haul}$ & \multicolumn{1}{c}{$\begin{array}{c}\text { Depth } \\
\mathrm{m})\end{array}$} & \multicolumn{1}{c}{$\mathrm{H}^{\prime}$} & $\mathrm{D}$ & $\mathrm{J}$ \\
\hline 8 & 555 & 0.87 & 3.43 & 0.25 & 27 & 478 & 1.20 & 366 & 0.33 \\
7 & 549 & 1.29 & 3.46 & 0.37 & 8 & 372 & 1.48 & 3.74 & 0.40 \\
4 & 593 & 1.37 & 3.61 & 0.38 & 12 & 573 & 1.60 & 3.58 & 0.45 \\
3 & 513 & 1.42 & 3.55 & 0.40 & 49 & 683 & 1.69 & 3.29 & 0.51 \\
9 & 523 & 1.66 & 3.49 & 0.47 & 19 & 583 & 1.83 & 3.49 & 0.52 \\
23 & 592 & 2.04 & 3.40 & 0.60 & 33 & 552 & 1.91 & 3.61 & 0.53 \\
5 & 654 & 2.09 & 2.88 & 0.72 & 31 & 553 & 1.91 & 3.33 & 0.57 \\
25 & 757 & 2.12 & 3.29 & 0.64 & 15 & 365 & 2.02 & 3.52 & 0.57 \\
2 & 613 & 2.17 & 3.40 & 0.64 & 4 & 505 & 2.02 & 3.66 & 0.55 \\
24 & 629 & 2.18 & 3.29 & 0.66 & 20 & 725 & 2.07 & 3.40 & 0.61 \\
20 & 621 & 2.25 & 3.04 & 0.74 & 39 & 651 & 2.14 & 3.08 & 0.69 \\
16 & 655 & 2.31 & 3.25 & 0.71 & 32 & 697 & 2.41 & 3.04 & 0.79 \\
6 & 343 & 2.41 & 3.63 & 0.66 & 30 & 605 & 2.64 & 3.46 & 0.76 \\
1 & 338 & 2.43 & 3.76 & 0.65 & 60 & 745 & 2.67 & 3.43 & 0.78 \\
& & & & & & & & & \\
Average & $\mathbf{5 6 6 . 8}$ & $\mathbf{1 . 9 0 1}$ & $\mathbf{3 . 3 9 1}$ & $\mathbf{0 . 5 6 4}$ & Average & $\mathbf{5 7 7 . 6}$ & $\mathbf{1 . 9 7 1}$ & $\mathbf{3 . 4 4 9}$ & $\mathbf{0 . 5 7 6}$ \\
\hline
\end{tabular}

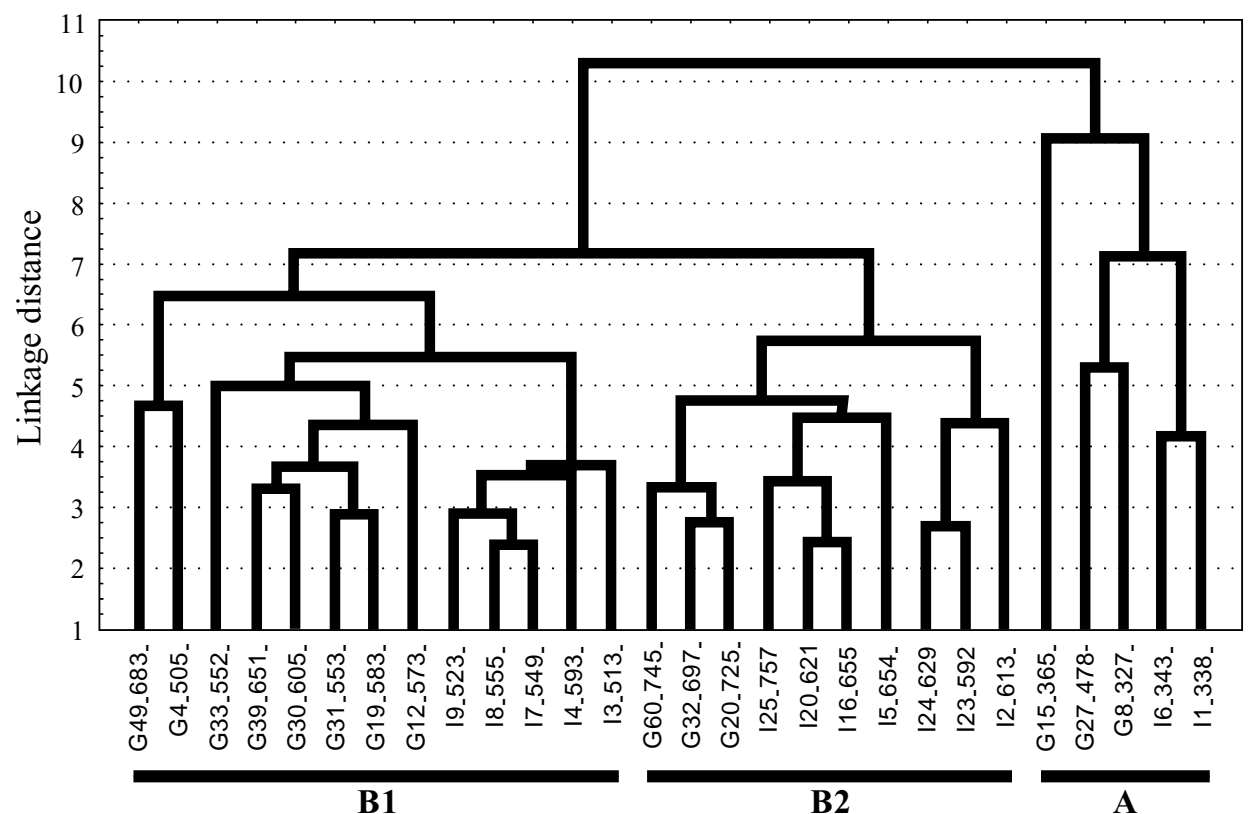

Fig. 2. Dendrogram related to the abundance values $(\mathrm{N} / \mathrm{h})$ of the species caught in the stations from Italian (I) and Greek (G) areas of the Ionian Sea (A = uppermost stations; B1 = intermediate stations; B2 = deepest stations).

studies (Hall, 1999, and references therein), is due to the different fishing intensity or to different environmental conditions.
At the upper slope depths, the lack of fishing pressure in the Greek area might explain the higher biomass computed for many species, the dominance 


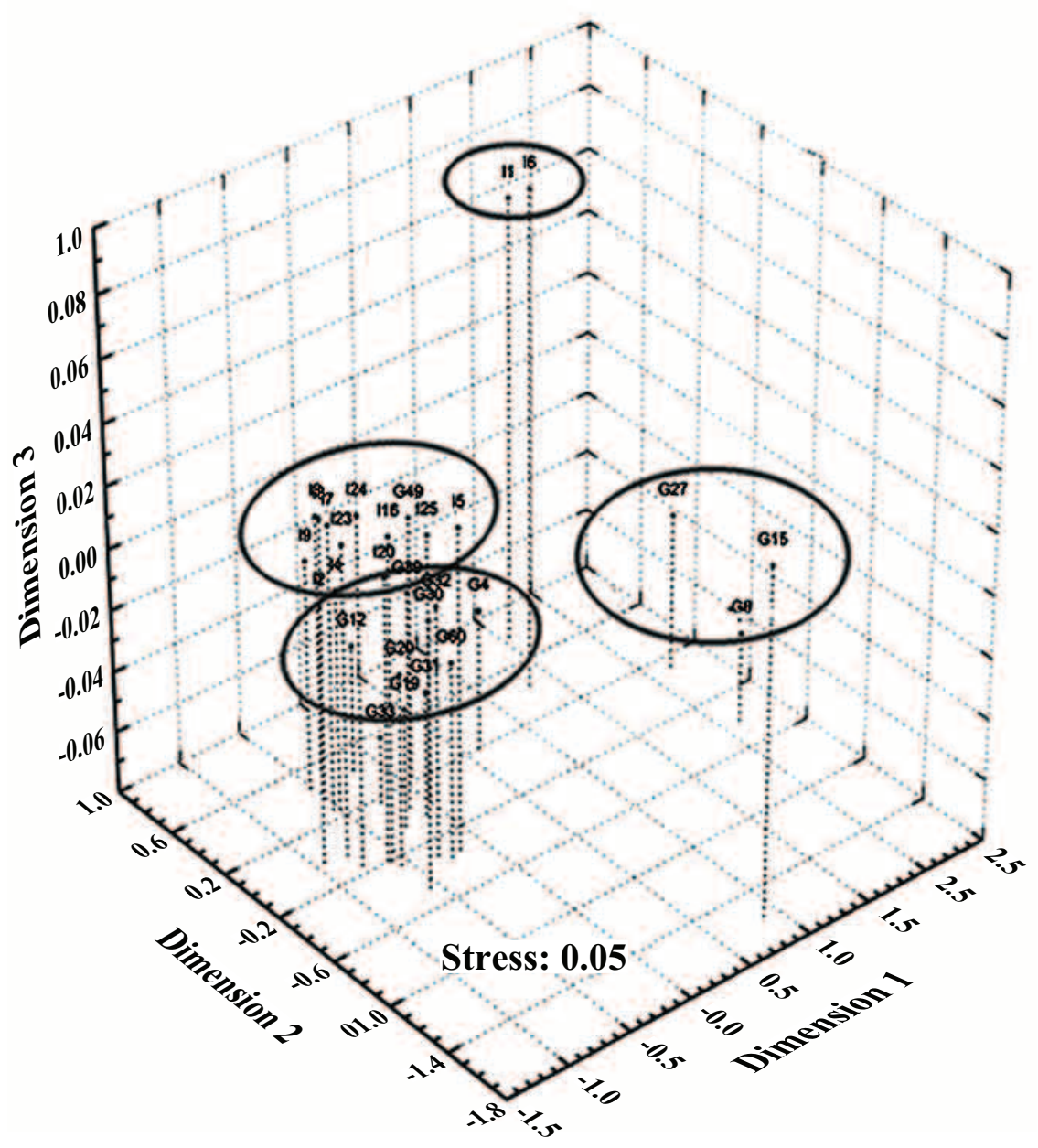

Fig. 3. Non-parametric multidimensional scaling (MDS) of different stations from Italian (I) and Greek (G) areas of the Ionian Sea.

of few species and the finding of a greater number of species and specimens of elasmobranchs. It is known that sharks are particularly vulnerable to overexploitation because of their k-selected life-history strategy (e.g. Stevens et al., 2000). However, the fact that both S. blainvillei and R. clavata have not been found in the North-western Ionian Sea, along the Italian coasts, since 1985 (Matarrese et al., 1996), while they are frequently caught in the neighbouring Sicilian Channel (Relini et al., 2000), where demersal resources are intensively exploited, indicates that the local environmental conditions should also be considered in order to explain species occurrence and distribution. This can also be seen for other species, such as Peristedion cataphractum, which is abundant both along the Ionian coasts of Greece and in the Sicilian Channel (Pizzicori et al., 1995), while it is rarely found along the Ionian coasts of Italy (Matarrese et al., 1996).
On the middle slope, the geographic characterization of the abundance of A. foliacea and $A$. antennatus might be related to the different hydrography and fishing intensity in the two areas. Along the Greek coast the water masses are warmer and have high salinity while along the Italian coast they are colder and slightly less saline (Robinson and Golnaraghi, 1992; Theocaris et al., 1993, Rabitti et al., 1994). According to Ghidalia and Bourgois (1961) and Bombace (1975), A. foliacea would be mainly linked to the former whereas $A$. antennatus mostly to the latter. Although the hydrographic hypothesis of Ghidalia and Bourgois (1961) needs to be confirmed, the Mediterranean distribution of the two species would seem to be in agreement with it (Relini and Orsi Relini, 1987; Murenu et al., 1994; Ragonese, 1995). However, there are no studies that have established other specific hypotheses on the different distribution of these two companion species. 
Concerning fishing, Affoliacea is considered to be more vulnerable to trawl fishing and less resilient than A. antennatus (Orsi Relini and Relini, 1985; Matarrese et al., 1997). In fact, while both juvenile and adult $A$. foliacea are almost exclusively distributed at depths where the bottom trawl fishing occurs, $A$. antennatus shows a wider vertical distribution. In addition to the deeper distribution and the lower availability to fishing of $A$. antennatus (Sardà, 1993), its higher density on the Italian side of the Ionian Sea and its higher fecundity (up to four times that of A. foliacea in the larger females, according to Orsi Relini and Semeria, 1983), seem to play an important role in the recovery of the stock. On the contrary, the lower density of $A$. foliacea along the Italian coasts together with its relatively shallower distribution and its low reproductive potential (Orsi Relini and Semeria, 1983), make it particularly vulnerable to trawling.

The lower abundance values recorded for $H$. dactylopterus in the Italian area seems to be a consequence of the exploitation of both the early life stages on the continental shelf and of the older stages on the slope where it completes its life cycle (D'Onghia et al., 1996). The higher similarity shown in the community structure of the two areas at the greatest depths might be explained by the presence of a large number of species whose depth distribution exceeds that of the trawl fishery, such as the macrourid fishes, $H$. mediterraneus, $P$. blennoides and $G$. melastomus, and therefore results in them being less vulnerable to fishing pressure.

Finally, although the present results are still preliminary, they seem to indicate that differences in biodiversity between the two study areas might be related to both fishing intensity and environmental conditions. Further data collection and analysis are required in order to evaluate the role of each process and how they interact.

\section{References}

ABELLA, A., and F. SERENA. 1995. Definizione di assemblaggi demersali nell'alto Tirreno. Biol. Mar. Medit., 2(2): 451453.

ABELlÒ, P., F. J. VALLADARES, and A. CASTELLÒN. 1988. Analysis of the structure of decapod crustacean assemblages off the Catalan coast (North-West Mediterranean). Marine Biology, 98: 39-49.

ANON. 1999. Developing deep water fisheries: data for their assessment and for understanding their interaction with and impact on a fragile environment. EC FAIR project $C T$ 95-0655. Final report of partner N. 6 (NCMR).
ANON. 2000. International bottom trawl survey in the Mediterranean (MEDITS Surveys 1998, 1999) Final Report. Projects: 97/25 IFREMER-CE, 97/13 IEO-CE, 97/69 SIBM-CE, 97/41 NCMR-CE.

BIAGI, F., S. DE RANIERI, M. MORI, P. SARTOR, and M. SBRANA. 1989. Preliminary analysis of demersal fish assemblages in the Northern Tyrrhenian Sea. Nova Thalassia, 10 Suppl. 1: 391-398.

BOMBACE, G. 1975. Considerazioni sulla distribuzione delle popolazioni di livello batiale con particolare riferimento a quelle bentoniche. Pubbl. Staz. Zool. Napoli, 39 suppl.: $7-21$.

CARTES, J. E., J. B. COMPANY, and F. MAYNOU. 1994. Deep-water decapod crustacean communities in the Northwestern Mediterranean: influence of submarine canyons and season. Marine Biology, 120: 221-229.

D'ONGHIA, G., A. TURSI, P. MAIORANO, A. MATARRESE, and M. PANZA. 1998. Demersal fish assemblages from the bathyal grounds of the north-western Ionian Sea. Ital J. Zool., 65 suppl.: 287-292.

D'ONGHiA, G., F. MASTROTOTARO, and M. PANZA. 1996. On the growth and mortality of rockfish, Helicolenus dactylopterus (Delaroche, 1809), from the Ionia Sea. FAO Fisheries Report, n. 533, Suppl.: 143152.

GHIDALIA, W., and F. BOURGOIS. 1961. Influence de la témperature et de l'éclairement sur la distribution des crevettes des moyennes et grandes profondeurs. Stud. Rev. Gen. Fish. Count. Medit., FAO, 16: 53 pp.

HALL, S. J. 1999. The Effects of Fishing on Marine Ecosystems and Communities. Fish Biology and Aquatic Resources. Series 1. Blackwell Science. 273 pp.

JENNINGS, S., and M. KAISER. 1998. The effects of Fishing on Marine Ecosystems. Advances in Marine Biology 34: $352 \mathrm{pp}$.

KRUSKAL, J. B. 1964. Multi-dimensional scaling by optimizing goodness of fit to a non-parametric hypothesis. Psychometrica, 29: 1-27.

LUDWIG, A. J., and J. F. REYNOLDS. 1988. Statistical Ecology - A primer on methods and computing. John Wiley \& Sons Eds.: 337 pp.

MAGURRAN, A. E. 1991. Ecological Diversity and its Measurement. Chapman and Hall, London.

MATARRESE, A., G. D'ONGHIA, A. TURSI, and M. BASANISI. 1996. New information on the Ichthyofauna of the south-eastern Italian coasts (Ionian Sea). Cybium, 20(2): 197-211.

MATARRESE, A., G. D'ONGHIA, A. TURSi, and P. MAIORANO. 1997. Vulnerabilità e resilienza in Aristaemorpha foliacea (Risso, 1827) e Aristeus antennatus (Risso, 1816) (Crostacei, Decapodi) nel Mar Ionio. S.It.E Atti, 18: 535-538.

MORANTA, J., E. MASSUTİ, and B. MORALES-NIN. 2000. Fish catch composition of the deep-sea decapod crustacean fisheries in the Balearic Islands (western Mediterranean). Fisheries Research, 45: 253-264.

MURA, M., and A. CAU. 1994. Community structure of the decapod crustaceans in the middle bathyal zone of the Sardinian Channel. Crustaceana, 67 (3): 259-266.

MURAWSKI, S. A. 2000. Definitions of overfishing from an 
ecosystem perspective. ICES Journal of Marine Science, 57: 649-658.

MURENU, A., D. CUCCU, C. FOLLESA, A. SABATINI, and A. CAU. 1994. The occurence of Aristaemorpha foliacea in Sardinia waters. In: Life cycles and fisheries of the deep-water red shrimps Aristaemorphe foliacea and Aristeus antennatus. Bianchini M. and Ragonese S. eds. N.T.R.-I.T.P.P. Special Publication, 3: 49 p.

ORSI RELINI, L., and M. SEMERIA. 1983. Oogenesis and fecundity in bathyal penaeid prawns, Aristeus antennatus and Aristaemorpha foliacea. Rapp. P.-V. Réun. CIESM, 28: 281-284.

ORSI RELINI, L., and G. RELINI. 1985. The red shrimps fishery in the Ligurian Sea: Mismanagement or not? FAO Fish. Rep., 336: 99-106.

PÉRÈS, J. M., and J. PICARD. 1964. Nouveau manuel de bionomie benthique de la Mer Méditerranée. Rec. Trav. St. Mar Endoume, 47: 138 p.

PIZZICORI, P., S. RAGONESE, and P. RIZZO. 1995 - Sulla distribuzione e biologia del pesce forca, Peristedion cataphractum L. 1758 (Peristedidae) nello Stretto di Sicilia (Mediterraneo Centrale). Biol. Mar. Medit. 2(2): 287-293.

POLITOU, C.-Y., M. KARKANI, and J. DOKOS. 2000. Distribution of decapods caught during MEDITS surveys in Greek waters. In: Demersal Resources in the Mediterranean. Coordinators J.A. Bertrand and G. Relini. IFREMER, Actes de Colloques, N.26: 196-207.

PRANOVI, F., S. RAICEVICH, G. FRANCESCHINI, M. G. FARRACE, and O. GIOVANARDI. 2000. Rapido trawling in the northern Adriatic Sea: effects on benthic communities in an experimental area. ICES Journal of Marine Science, 57: 517-524.

RABITTI, S., F. BIANCHI, A. BOLFRIN, L. DA ROS, G. SOCAL, and C. TOTTI. 1994. Particulate matter and phytoplankton in Ionian Sea. Oceanologica Acta, 17(3): 297-307.

RAGONESE, S. 1995. Geographical distribution of Aristaeomorpha foliacea (Crustacea: Aristeidae) in the Sicilian Channel (Mediterranean Sea). ICES Mar. Sci. Symp., 199: 183-188.

RELINI, G., F. BIAGI, F. SERENA, A. BELLUSCIO, M. T. SPEDICATO, P. RINELli, M. C. FOLlESA, C. PICCINETTI, N. UNGARO, L. SION, and D. LEVI. 2000. I Selaci pescati con lo strascico nei mari italiani. Biol. Mar. Medit., (7)1:347-384.

RELINI, G., and L. ORSI RELINI. 1987. The decline of red shrimps stocks in the Gulf of Genoa. Inv. Pesq., 51 (suppl. 1): 245-360.

ROBINSON, A. R., and M. GOLNARAGHI. 1992. Progress in the understanding of the eastern Mediterranean Sea. Bulletin de l'Institut océanographique, Monaco, No. special 11: 65-73.

SARDÀ, F. 1993. Bio-ecological aspects of the decapod crustacean fisheries in the Western Mediterranean. Aquat. Liv. Resour., 6: 299-305.

STATSOFT. 1995. STATISTICA release 5 for Windows operating system by StatSoft.

STEFANESCU, C., B. MORALES-NIN, and E. MASSUTİ. 1994. Fish assemblages on the slope in the Catalan Sea (Western Mediterranean): influence of a submarine canyon. J. mar. biol. Ass. U.K., 74: 499-512.

STERGIOU, K. I., C.-Y. POLITOU., E. D. CHRISTOU, and G. PETRAKIS. 1997. Selectivity experiments in the NE Mediterranean: the effect of trawl codend mesh size on species diversity and discards. ICES Journal of Marine Science, 54: 774-786.

STEVENS, J. D., R. BONFIL, N. K. DULVY, and P.A. WALKER. 2000. The effects of fishing on sharks, rays, and chimaeras (chondrichthyans), and the implications for marine ecosystem. ICES Journal of Marine Science, 57: 476-494.

THEOCHARIS, A., D. GEORGOPOULOS, A. LASCARATOS, and K. NITTIS. 1993. Water masses and circulation in the central region of the Eastern Mediterranean: Eastern Ionian, South Aegean and Northwest Levantine, 1986-1987. In: Topical studies in Oceanography, Part. II, A.R. Robinson and P. MalanotteRizzoli editors. Deep-Sea Res., 40, 6: 1121-1142.

TURSI, A., and G. D'ONGHIA. 1992. Cephalopods of the Ionian Sea (Mediterranean Sea). OEBALIA, XVIII, N.S.: 25-43.

TURSI, A., A. MATARRESE, G. D'ONGHIA, P. MAIORANO, and M. PANZA. 1998. Sintesi delle ricerche sulle risorse demersali del Mar Ionio (da Capo d'Otranto a Capo Passero) realizzate nel periodo 1985-1997. Biol. Mar. Medit., 5(3): 120-129.

UNGARO, N., G. MARANO, R. MARSAN, and K. OSMANI. 1998. Demersal fish assemblage bio-diversity as an index of fishery resources exploitation. Ital. J. Zool., 65, Suppl.: 511516.

UNGARO, N., G. MARANO, and R. VACCARELLA. $1995-$ Comparazione tra aree batiali strascicabili del basso Adriatico mediante l'utilizzo dell'analisi fattoriali delle corrispondenze. Biol. Mar. Medit., 2 (2): 185-189. 
